\title{
Neurochemistry of Love: Can Romantic Love Truly be Addictive?
}

\section{Md. Sahab Uddin*}

Department of Pharmacy, Southeast University, Dhaka, Bangladesh

\section{Editorial}

Love is a multifarious neurobiological marvel which relies on the activity of brain reward system that comprises countless neurotransmitter and hormone. It is the forerunner for several getting utmost of the human being during the ages. Emotional linkage and sensory stimulus to someone are the supreme denouements of love [1]. Therefore, it was speculated that the relevant neural tracks intricate might be communal in the neural paths regulating appetitive, reward, pleasure, as well as addictive behaviours. Diverse neural paths, with varied neurotransmitters, regulate the three foremost phases of love (i.e., lust, attraction and attachment) that are accountable for falling in love [2].

The first phase of love is lust characterized by the longing for sexual pleasure [2]. The researchers suggested that sex hormones especially testosterone and estrogen are the vital hormones to initiate love [3]. In the sex drive for male, testosterone and for female, estrogen plays an acute role. The study of Marazziti and Canale reported that during falling in love, men generate lower testosterone and follicle-stimulating hormone levels, but women generate more [4]. These sex hormones persuade short-term physiological as well as behavioural alterations and eradicating ultimate biological variations amid the sexes. Like addicts, lovers, also often go to extremes. This is represented by the aggressive sexual affection owing to the stimulation of testosterone receptors in certain areas of brain typically hypothalamic to convert testosterone into estrogen that exerts a rise in aggressiveness [5,6]. Delville et al. stated that testosterone also excites the genesis of vasopressin by modulating vasopressin receptors in the hypothalamus, linked to aggressiveness [7].

Attraction is the second phase of love, characterized by augmented energy and intensive attention on one or more possible mates [2]. This time period of this phase is amazing, loss of sleep, as well as appetite and fantasizing about the lover are main signs. Monoamines neurotransmitters mainly epinephrine, dopamine and serotonin may be active to endorse attraction. Epinephrine plays an imperative role in the fight-or-flight retort by rising blood flow [8]. Dopamine is often called the pleasure chemical. Marazziti et al. inspected high levels of the dopamine in romantic lovers [9]. Studies suggested that dopamine excites desire and reward paths and engender a feeling of great pleasure $[10,11]$. Furthermore, deluge dopamine amid couples may cause intensive attention and superb pleasure in the least facts of this relationship. Several functional magnetic resonance imaging studies exposed that the exposure to pictures of the romantic partner to lovers induced neural triggering in the right ventral tegmental area, the right caudate nucleus and the putamen, areas all enrich in dopamine $[12,13]$. Conversely, serotonin is causative to inhibit sexual activity and thus may contribute to optimistic mood (i.e., mental calmness) [14].

The last phase of love is attachment characterized by the maintenance of close relationship amid couples and raise children [2]. Oxytocin and vasopressin are the foremost hormones linked to attachment $[15,16]$. In the physiology of love, oxytocin is accountable for stress discount by impeding the discharge of corticoids. Studies suggested that pair bonding, as well as social attachments are denouements of oxytocin
[17]. Insel et al. described that oxytocin, discharged with mating, may be essential to making a partner liking in the female prairie vole [18]. Instead, vasopressin is responsible for maintaining the lasting promise [17]. The study suggested that when male prairie voles were treated with vasopressin antagonists failed to display aggression to secure the female mate and did not give as much time with the original mate as with new potential mates. However, treatment by vasopressin was associated with reverse effect and became aggressive to other males and favoured to devote time with their partner than with foreigners [19-21]. Therefore, vasopressin and oxytocin exhibit an association amid physiological love-signalling and following social or protective behaviours.

Romantic love in a relationship is characterized by the aspiration to enter and/or keep a close relationship amid opposite sex. Combinations of behaviours, cognitions and emotions components are linked to this form of love for the purpose of mate doubling, attachment and intrasexual rivalry [22]. The role of several neurochemicals (i.e., dopamine, serotonin, oxytocin and vasopressin) and neural activities arising within the brain of lovers are already stated. But alike neurochemicals are also linked with addictive drugs (i.e., amphetamines, heroin, or cocaine) [23-25]. Burkett and Young suggested a strong and logical concord amid the brain areas and the chemistry of neurochemicals intricate in addiction as well as the social attachment [26].

One can fall in romantic love at any age of life but love is usual amid teenagers. Mature and healthy loves are the prerequisite for a relationship. Sussman recommends that amid mature and immature love, only the latter (i.e., immature) may be dignified a form of addiction [27]. Erich Fromm, in "The Art of Loving," stated, immature love says: 'I love you because I need you' and mature love says: 'I need you because I love you' [28]. The first statement is based on dependency and it may associate with addiction (Figure 1). But the second one is based on uniqueness, essentialness and essentiality. Is not it?

Compromise and understanding are two important parts for love or arranged marriage. Several reports suggested that the rate of divorce is higher in love marriages with respect to arranged ones due to unfeasible fancy and astounded prospects [29]. This phenomenon is extremely higher in Western countries [30] compared to Asian. Burkett and Young claimed that generally romantic relations acknowledged from falling in love to eventual separation and following withdrawal that may be reflected as an addiction [26].

*Corresponding author: Md. Sahab Uddin, Department of Pharmacy, Southeast University, Dhaka, Bangladesh, Tel: +8801710220110; E-mail: msu_ neuropharma@hotmail.com, msu-neuropharma@hotmail.com.

Received: November 03, 2017; Accepted: November 05, 2017; Published: November 12, 2017

Citation: Uddin MS (2017) Neurochemistry of Love: Can Romantic Love Truly be Addictive? J Psychiatry 21: e113. doi:10.4172/2378-5756.1000e113

Copyright: (C) 2017 Uddin MS. This is an open-access article distributed under the terms of the Creative Commons Attribution License, which permits unrestricted use, distribution, and reproduction in any medium, provided the original author and source are credited 


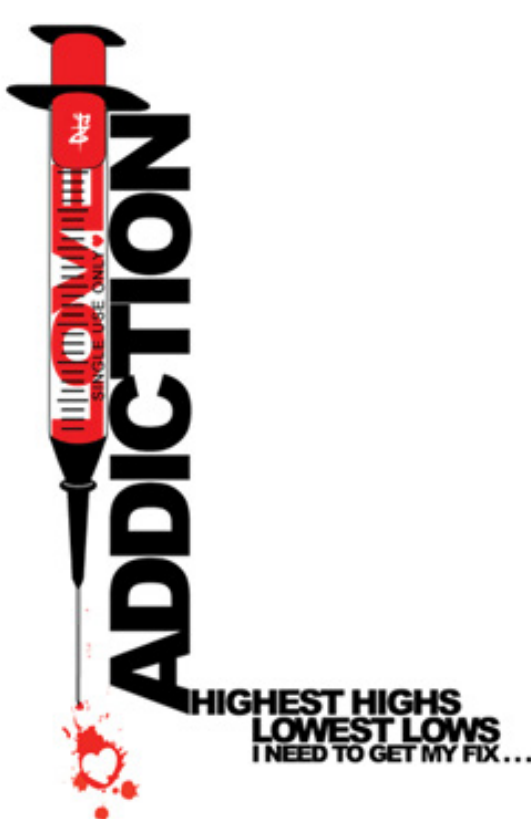

Figure 1: Romantic love is a natural addiction and this genre of addiction is just like appetite and everyone is addicted.

Dopamine is fervor, lust, adultery, motivation, attention, feminism and addiction. Not only these, dopamine is also associated with a rife range of processes linked to reward learning - comprising eating, drinking, love and sex [31]. Researchers suggested that dopaminergic overlap may clarify the fact of feeling love or affable in sexual intercourse can generate the feeling of a cocaine rush [32]. Numerous neuroimaging support for an overlap amid love-addiction and drug-addiction derives from studies in which exposure of the images of romantic partners induce not only self-reported feelings of love and optimistic affect but also show substantial triggering in brain's reward regions $[33,34]$.

Romantic love can be literally addictive but truly not [31]. There are numerous differences amid natural reward (i.e., romantic love) and artificial reward (i.e., drugs of abuse). The natural reward is not long lasting like addictive drugs [35]. Moreover, the natural reward is controlled by feedback mechanisms that lead to a faster return to baseline, but the artificial reward is not like this phenomenon [36]. The main drive of love is to produce replica by reproduction [37]. On the other hand, addictive drugs are the hijacking mechanisms of the reward functions $[38,39]$ that lead to destruction. As stated earlier, rejection is common for romantic lovers but drug addicts are not ever refused by their drug [31].

The capacity to form significant and lasting relationships is an imperative social aptitude. Romantic love may be considered as a natural addiction. Drugs addiction is highly associated with deleterious magnitudes, but romantic love is an affirmative addiction when the relationship is communal, non-noxious and apt.

\section{Acknowledgements}

The author wishes to thank the anonymous reviewer(s)/editors(s) of this article for their constructive reviews.

\section{Competing Interests}

The author proclaims no competing interests.

\section{References}

1. Fisher H (2004) Why we love: The nature and chemistry of romantic love. Holt Paperbacks, New York.

2. Fisher $\mathrm{H}$ (1998) Lust, attraction, and attachment in mammalian reproduction. Human Nat 9: 23-52.

3. Yovell $Y(2008)$ Is there a drive to love? Neuro-Psychoanaly 10: 117-188.

4. Guyton AC, Hall, JE (2006) Textbook of medical physiology.

5. Marazziti D, Canale D (2004) Hormonal changes when falling in love Psychoneuroendocrino 29: 931-936.

6. Willmer P, Stone G, Johnston I (2004) Environmental physiology of animals. John Wiley \& Sons, New York.

7. Uddin MS (2017) Brain chemistry and sex differences: Are male and female brains really varied? Neuro Neuropharm 3: 1-3.

8. Delville Y, Mansour KM, Ferris CF (1996) Testosterone facilitates aggression by modulating vasopressin receptors in the hypothalamus. Physiol Behav 60: 25-29.

9. Harvey RA, Clark MA, Finkel R (2012) Lippincott's illustrated reviews pharmacology (5th edn.). Lippincott Williams \& Wilkins, New York.

10. Marazziti D, Baroni S, Giannaccini G, Piccinni A, Mucci F, et al. (2017) Decreased lymphocyte dopamine transporter in romantic lovers. CNS Spectr 22: 290-294.

11. Paredes RG, Agmo A (2004) Has dopamine a physiological role in the control of sexual behavior? A critical review of the evidence. Prog Neurobiol 73: 179-226.

12. Pfaus JG (2009) Pathways of sexual desire. J Sex Med 6: 1506-1533.

13. Bartels A, Zeki S (2000) The neural basis of romantic love. Neuroreport 2711: 3829-3834.

14. Fisher H, Aron A, Brown LL (2005) Romantic love: An fMRI study of aneural mechanism for mate choice. J Comp Neurol 493: 58-62.

15. Shankar GS (2016) Serotonin and sexual dysfunction. J Autac Horm 5: 1-2.

16. Amran MS, Uddin MS (2014) Pharmakon comprehensive pharmaceutical pharmacology. Krishnachura Prokashoni, Dhaka.

17. Reis HT, Sprecher S (2009) Encyclopedia of human relationships. SAGE Publishing, New York.

18. Hammock EA, Young LJ (2006) Oxytocin, vasopressin and pair bonding implications for autism. Philos Trans R Soc Lond B Biol Sci 361: 2187-2198.

19. Insel TR, Hulihan T (1995) A gender-specific mechanism for pair bonding: oxytocin and partner preference formation in monogamous voles. Behav Neurosci 109: 782-789.

20. Winslow JT, Hastings N, Carter CS, Harbaugh CR, Insel TR (1993) A role for central vasopressin in pair bonding in monogamous prairie voles. Nature 365 : 545-548.

21. Young LJ, Wang $Z$ (2004). The neurobiology of pair bonding. Nat Neurosci 7 : 1048-1054.

22. McGraw LA, Young LJ (2010) The prairie vole: an emerging model organism for understanding the social brain. Tre Neurosci 33: 103.

23. Diamond LM, Dickenson JA (2012) The neuroimaging of love and desire: Review and future directions. Clin Neuropsychiatry 9: 39-46.

24. Uddin MS, Sufian MA, Kabir MT, Hossain MF, Nasrullah M, et al. (2017) Amphetamines: Potent recreational drug of abuse. J Addict Res Ther 8: 1-12.

25. Uddin MS, Sufian MA, Hossain MF, Kabir MT, Islam MT, et al. (2017) Neuropsychological effects of caffeine: Is caffeine addictive? J Psychol Psychother 7: 1-12.

26. Uddin MS (2017) Sugar and reward system: Is high sugar intake generating akin effects like drugs of abuse? Ment Health Addict Res 2: 1-2.

27. Burkett JP, Young LJ (2012) The behavioral, anatomical and pharmacological parallels between social attachment, love and addiction. Psychopharmaco 224 $1-26$.

28. Sussman S (2010) Love addiction: Definition, etiology, treatment. J Treat Preven 17: 31-45. 
29. No Authors Listed (2017) What Is Real True Love?

30. No Authors Listed (2017) In 2015, divorce rate was high in love marriages in Gujranwala: report

31. No Authors Listed (2017) Why is the divorce rate so high, especially in Western countries, if love marriages work?

32. Earp BD, Wudarczyk OA, Foddy B, Savulescu J (2017) Addicted to love: What is love addiction and when should it be treated? Philos Psychi Psycho 24: 77-92.

33. Blum K, Werner T, Carnes S, Carnes P, Bowirrat A, et al. (2012) Sex, drugs, and rock ' $n$ ' roll: hypothesizing common mesolimbic activation as a function of reward gene polymorphisms. J Psychoac Drugs 44: 38-55.

34. Aron A, Fisher H, Mashek DJ, Strong G, Li H, et al. (2005) Reward, motivation, and emotion systems associated with early-stage intense romantic love. J Neurophysio 94: 327-337.
35. Fisher HE, Aron A, Brown LL (2006) Romantic love: A mammalian brain system for mate choice. Philos Trans R Soc Lond B Biol Sci 361: 2173-2186.

36. Esch T, Stefano GB (2005) The neurobiology of love. Neuroendocrino Lett 26 175-192.

37. Small DM, Zatorre RJ, Dagher A, Evans AC, Jones-Gotman M (2001) Changes in brain activity related to eating chocolate: From pleasure to aversion. Brain 124: 1720-33.

38. Blum K, Chen LC, Giordano J, Borsten J, Chen TJH, et al. (2012) The addictive brain: All roads lead to dopamine. J Psychoactive Drugs 44: 134-143.

39. Hyman S (2007) The neurobiology of addiction: implications for voluntary control of behavior. American J Bioethics 7: 8-11. 